\title{
Determining specific biomass activity in anaerobic wastewater treatment processes
}

\author{
S. Petrozzi, N. Mol and I. J. Dunn, Zurich, Switzerland
}

\begin{abstract}
An experimental method for the measurement of specific gas production rate was developed and tested with biomass samples taken from anaerobic fluidized bed reactors, operating with a variety of carriers with molasses, condensate from cellulose production and brewery wastewater as feeds. The method is based on reactor sampling and offline gas volume measurement during a known time interval. Important factors are biomass and liquid sampling under oxygen-free conditions, using the liquid from the reactor as substrate, providing sufficient mixing and maintaining the physical integrity of the biomass. The method was developed in such a way that small samples $(20 \mathrm{ml})$ were taken under anaerobic conditions (poising agent) for short-term (2-3 min.) gas rate measurements in a small fluidized bed $(25 \mathrm{ml})$ batch reactor with $U$-tube. Biomass content was measured by an instrumental nitrogen method (Dumas), followed by weight determination of the carrier. The gas rates measured with the test system, and their dependence on substrate concentration, were in good agreement with those directly measured from the continuous fluidized bed reactor. Additions of molasses and acetate to the sample proved that the influence of concentration on the biomass activity can be obtained only by operating the continuous reactor at the concentration levels of interest. Comparison between the reactors showed large differences in the specific activity and the total reactor activity. It was found when comparing two reactors, that the values of the specific and the total activities permitted the calculation of the relative biomass quantities. In this way the influence of the carrier-type could be evaluated.
\end{abstract}

\section{Introduction}

The most significant indicator of operational performance in anaerobic degradation processes is the rate of gas production, since the last step in the complex sequence is methane production. It can be related to COD degradation since theoretically $1 \mathrm{~g} \mathrm{COD}$ is converted into $350 \mathrm{ml}$ methane (STP) or $1 \mathrm{ml} \mathrm{CH}_{4}$ (STP) corresponds to $2.86 \mathrm{mg} \mathrm{COD}$. It is a direct measure of the activity of the methanogenic bacteria and can be obtained directly from laboratory reactors by a variety of techniques [1]. The relationship between the degradation and the cumulative gas production was used to assess the anaerobic biodegradability [2]. Gas rate depends on the biomass quantity and its specific activity. The activity of the biomass in a reactor is critical for its effectiveness in wastewater treatment. In previous work on the use of various carriers in a fluidized bed, the $\mathrm{kg}$ biomass per $\mathrm{kg}$ carrier was measured, and it was found that despite more than two times higher biomass content on a porous glass carrier, a quartz sand system gave the same degradation rates [3]. In subsequent work, in which the influence of carrier in AFBR was investigated, it was found that thin biofilms performed better than thick ones [4]. The reasons for this are uncertain; it could be that beyond a critical thickness substrate diffusion becomes a limiting factor or that thicker films contain non-viable biomass. In the above work, a specific activity measurement would have provided additional information on the condition of the reactor. Unfortunately, a method for such measurements was not available.

Certain equipment and methods have been used to measure activity in reactors. U-tubes have been used to measure the gas volume, with the disadvantage that the pressure varies but having the advantage that they are easy to set up [5] and automate [6]. Offline, batch measurement cells involving liquid level in a straight tube manometer have been employed [7]. A continuously operated minireactor was monitored with an automated U-tube device to measure both gas rate and total gas production [6]. This has similarities with the device used in the present work. Pressure transducers can be used on batch reactors with very small gas rates $[8,9]$. Yamada et al. [10] investigated the suitability of the MS with membrane inlet and batch measurement cell for obtaining kinetic data from anaerobic mixed cultures.

The goal of the present work was to develop a method for anaerobic reactor sampling, biomass activity measurement and subsequent determination of the total sample biomass.

\section{Experimental methods}

Three waste waters were used in the course of this work: Molasses, condensate from cellulose manufacture and brewery waste. Their important characteristics (feed concentrations and composition) are given in Table 1. The latter two waste streams were degraded in parallel fluidized bed reac- 
Table 1. Feed concentrations and compositions

\begin{tabular}{|c|c|c|}
\hline & Feed concentration & Feed composition \\
\hline Molasses & $0.72 \mathrm{~kg} \mathrm{COD} / \mathrm{kg}$ & $\begin{array}{l}20 \% \text { Water } \\
50 \% \text { Saccharose } \\
20 \% \text { Amino acids } \\
10 \% \text { Trace elements }\end{array}$ \\
\hline $\begin{array}{l}\text { Vapour } \\
\text { condensate }\end{array}$ & $\begin{array}{l}5-8 \mathrm{~kg} \mathrm{COD} / \mathrm{m}^{3} \\
2-4 \mathrm{~kg} \mathrm{TOC} / \mathrm{m}^{3}\end{array}$ & $\begin{array}{ll}\text { Furfurol } & 5-10 \mathrm{~g} / \mathrm{m}^{3} \\
\text { Methanol } & 50 \mathrm{~g} / \mathrm{m}^{3} \\
\text { Acetic acid } & 0.8-1 \mathrm{~kg} / \mathrm{m}^{3}\end{array}$ \\
\hline $\begin{array}{l}\text { Brewery } \\
\text { wastewater }\end{array}$ & $\begin{array}{l}2-8 \mathrm{~kg} \mathrm{COD} / \mathrm{m}^{3} \\
0.6-3 \mathrm{~kg} \mathrm{TOC} / \mathrm{m}^{3}\end{array}$ & $\begin{array}{l}\text { Phosphate } 40-76 \mathrm{~g} / \mathrm{m}^{3} \\
\text { Sulphate } \quad 33-51 \mathrm{~g} / \mathrm{m}^{3}\end{array}$ \\
\hline \multicolumn{3}{|c|}{$\begin{array}{l}\text { Supplemented micronutrients used in the feed. Principle wastewater } \\
\text { component (molasses, condensate, and brewery): }\end{array}$} \\
\hline $\begin{array}{l}\text { Compound } \\
\mathrm{KH}_{2} \mathrm{PO}_{4} \cdot \mathrm{H}_{2} \mathrm{O} \\
\mathrm{NH}_{4} \mathrm{Cl} \\
\mathrm{CaCl}_{2} \\
\mathrm{MgCl}_{2} \cdot 6 \mathrm{H}_{2} \mathrm{O}\end{array}$ & $\begin{array}{l}\text { Concent } \\
300 \\
200 \\
130 \\
500\end{array}$ & ion in feed (mg/l) \\
\hline $\begin{array}{l}\text { Trace elements: } \\
\mathrm{FeSO}_{4} \cdot 7 \mathrm{H}_{2} \mathrm{O} \\
\mathrm{MnCl}_{2} \cdot 4 \mathrm{H}_{2} \mathrm{O} \\
\mathrm{CaCl}_{2} \cdot 2 \mathrm{H}_{2} \mathrm{O} \\
\mathrm{ZnCl} \\
\mathrm{CoCl}_{2} \cdot 6 \mathrm{H}_{2} \mathrm{O} \\
\mathrm{NiSO}_{4} \cdot 6 \mathrm{H}_{2} \mathrm{O} \\
\mathrm{H}_{3} \mathrm{BO}_{3} \\
\mathrm{Na}_{2} \mathrm{MoO}_{4} \cdot 2 \mathrm{H}_{2} \\
\mathrm{CuCl}_{2} \cdot 2 \mathrm{H}_{2} \mathrm{O} \\
\mathrm{NH}_{4} \cdot \mathrm{VO}_{3} \\
\text { Sodium citrate } \\
\text { Resazurine }\end{array}$ & $\begin{array}{c}13.0 \\
3.16 \\
1.48 \\
2.16 \\
1.92 \\
1.33 \\
1.00 \\
1.00 \\
0.67 \\
0.67 \\
117.67 \\
1.0\end{array}$ & \\
\hline
\end{tabular}

Table 2. Carriers characteristics

\begin{tabular}{lllc}
\hline Carrier & $\begin{array}{l}\text { Particle size } \\
(\mathrm{mm})\end{array}$ & $\begin{array}{l}\text { Density } \\
\left(\mathrm{kg} / \mathrm{m}^{3}\right)\end{array}$ & $\begin{array}{l}\text { Micropore area } \\
\left(\mathrm{m}^{2} / \mathrm{kg}\right)\end{array}$ \\
\hline Pumice & $0.2-0.315$ & 1650 & 82.3 \\
Quartz sand & $0.2-0.315$ & 2600 & 20.3 \\
Shale & $0.2-0.315$ & 1870 & 59.1 \\
Activated carbon & $0.2-0.315$ & 1250 & 645,000 \\
\hline
\end{tabular}

tors with various carriers, whose important characteristics are as given in Table 2. The molasses-fed reactor contained only crushed quartz sand $(0.2-0.3 \mathrm{~mm})$. Operation of the reactors involved varying the liquid feed rates to establish a range of steady-state concentration conditions $\left(S_{1}\right)$. Gas rates and reaction rates were measured on the reactors directly. Samples were taken for the offline gas rate and specific gas rate measurements in the batch test reactor.

The 0.81 continuous reactors consisted of standard glass parts fitted together with tapered joints as shown in Fig. 1. The reactor columns $(70 \times 3 \mathrm{~cm})$ had a conical upper settling zone with a diameter of $10 \mathrm{~cm}$. Below this settling zone a sampling tube was installed to obtain liquid and bioparticle samples. Each reactor contained $100 \mathrm{ml}$ settled volume of solid carrier material. The upflow velocity rate was adjusted

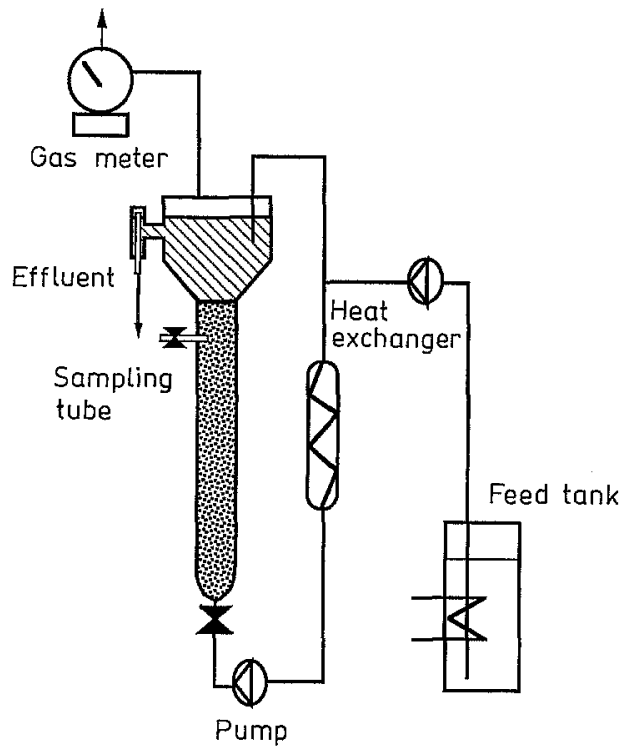

Fig. 1. Schematic drawing of the continuous fluidized bed reactor, 0.81

to achieve an expansion between 50 and $200 \%$ of the bed. Circulation and fluidization flow rates were maintained with a peristaltic pump using Marprene tubing (required for durability). The reactors were fed continuously, and constant volume was maintained with an overflow. Thermostating maintained a temperature of $37^{\circ} \mathrm{C}$. Gases were collected via an outlet at the top of the reactor in a wet gas meter (Wohlgroth) and reported at $10^{5} \mathrm{~Pa}$ and $20^{\circ} \mathrm{C}$. Additional substances added to the feed solutions were as given in Table 3. Chemical oxygen demand (COD) was measured on filtered $(0.45 \mu \mathrm{m})$ samples using a commercial colorimetric test system (Nanocolor) for the evaluation of reactor performance.

The nitrogen content of the biomass was analysed by the Dumas method using an automated instrument (Leco), which involved oxidation at $850^{\circ} \mathrm{C}$. The nitrogen oxides were then quantified by a thermal conductivity detector. The nitrogen content of the liquid was analysed by the Kjehldahl method and the ammonia-nitrogen by ion chromatography. The total nitrogen balance showed that nitrogen determined in the biofilm was mainly organic. Dry weight was found to be linearly related to nitrogen content but its measurement was less accurate. Other specific biomass indicators such as DNA, protein [11], ATP and dehydrogenase $[12,13]$ might be possible but measurement of these parameters would require more effort. Therefore in this work nitrogen content of the sample was taken in place of biomass for the specific activity calculation.

Specific gas $\left(\mathrm{CH}_{4}+\mathrm{CO}_{2}\right)$ production rates were measured in a specially designed, thermostated, 0.0251 , plexiglass test batch reactor (TBR), as shown in Fig. 2, by displacement of liquid (ethyl iodide, $d=1.93 \mathrm{~g} / \mathrm{ml}$ ) in a $0.05 \mathrm{~mm}$ i.d. glass U-tube. Various chambers and methods of stirring were tested, including a mini-fluidized bed, propeller 


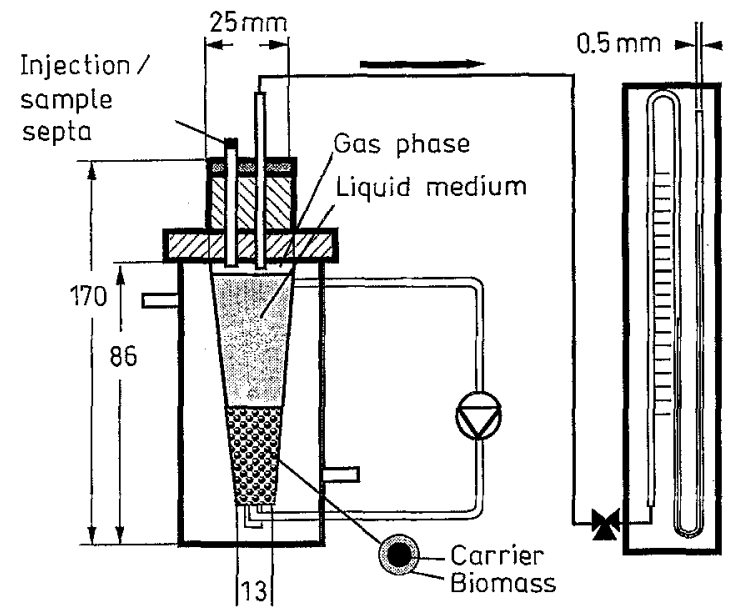

Fig. 2. Test batch reactor TBR with $U$-tube

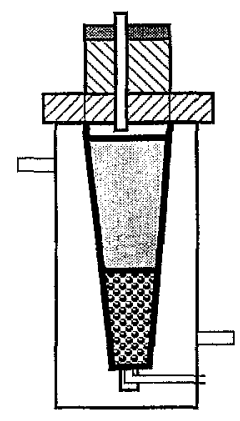

MFB

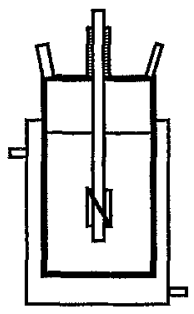

$\mathrm{P}$

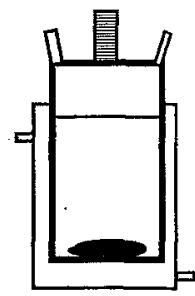

MS
Fig. 3. Various mixing devices for the TBR (see Table 4). MFB: Mini fluidized bed, P: Propeller, MS: Magnetic stirrer

Table 3. Activity measurements on the 0.81 reactor (liquid and solid phases) using the test batch reactor TBR

\begin{tabular}{lll}
\hline $\begin{array}{l}\text { Substrate } \\
\text { reactor conc. } \\
\left(\mathrm{kg} \mathrm{COD} / \mathrm{m}^{3}\right)\end{array}$ & $\begin{array}{l}\text { Gas rate/ } \\
\text { Vol. sand } \\
(\mu \mathrm{L} / \mathrm{min} \mathrm{ml})\end{array}$ & $\begin{array}{l}\text { Gas rate/ } \\
\text { Vol. liquid } \\
(\mu \mathrm{l} / \mathrm{min} \mathrm{ml})\end{array}$ \\
\hline 1.5 & 21 & 0.3 \\
2.1 & 41 & 0.3 \\
4.3 & 100 & 0.4 \\
\hline
\end{tabular}

Table 4. Various mixing and sample conditions in test batch reactor

\begin{tabular}{|c|c|c|}
\hline $\begin{array}{l}\text { Mini } \\
\text { fluidized bed } \\
\text { (MFB) } \\
(0.0251)\end{array}$ & $\begin{array}{l}\text { Propeller } \\
(\mathrm{P}) \\
(0.061)\end{array}$ & $\begin{array}{l}\text { Magnetic stirrer } \\
(\mathrm{MS}) \\
(0.0251)\end{array}$ \\
\hline $\begin{array}{l}\text { 1) Sand/Sample } \\
(\mathrm{ml} / \mathrm{ml}) \\
1: 8\end{array}$ & $\begin{array}{l}\text { 3) Sand/Sample } \\
(\mathrm{ml} / \mathrm{ml}) \\
1: 5 \\
\text { Stirring speed } 750 \mathrm{rpm}\end{array}$ & $\begin{array}{l}\text { 5) Sand/Sample } \\
(\mathrm{ml} / \mathrm{ml}) \\
1: 13 \\
\text { Stirring speed } 50 \mathrm{rpm}\end{array}$ \\
\hline $\begin{array}{l}\text { 2) Sand/Sample } \\
(\mathrm{ml} / \mathrm{ml}) \\
1: 19\end{array}$ & $\begin{array}{l}\text { 4) Sand/Sample } \\
(\mathrm{ml} / \mathrm{ml}) \\
1: 10 \\
\text { Stirring speed } 750 \mathrm{rpm}\end{array}$ & $\begin{array}{l}\text { 6) Sand/Sample } \\
(\mathrm{ml} / \mathrm{ml}) \\
1: 5 \\
\text { Stirring speed } 250 \mathrm{rpm}\end{array}$ \\
\hline
\end{tabular}

and magnetic stirrer systems, as shown in Fig. 3. The apparatur was placed in a thermostated box and controlled at $37^{\circ} \mathrm{C}$.

The U-tube calibration was done by injecting a known volume of air (saturated with water at $37^{\circ} \mathrm{C}$ ) into the TBR without biomass. The response was linear in spite of the pressure difference due to the liquid column. Ethyl iodide was chosen because of its non-wetting properties, but it is volatile and had to be calibrated every two days.

The gas rates were measured manually from the liquid column height to an accuracy of $1 \mathrm{~mm}$ and typically over a $1 \mathrm{~min}$. period corresponding to an accuracy in gas rate of $0.01 \mathrm{ml} / \mathrm{min}$. The amount of sand in the sample was compared by its settled volume to the sand volume in the reactor; this ratio was used to scaleup the batch cell measurements.

Sampling of anaerobic biomass is critical because methanogenic bacteria require negative redox potential conditions. Two sampling procedures were tested: A syringe method and a direct vacuum sampling method. The syringe method involved withdrawing $25 \mathrm{ml}$ from the reactors with a hypodermic needle. The syringe had been previously rinsed with nitrogen gas and contained $2 \mathrm{ml}$ of $100 \mathrm{mM}$ cysteine solution as poising agent and resazurine as redox indicator. (Poising is analogous to buffering in the context of $\mathrm{pH}$.) The sample was injected into the batch cell, which had been evacuated. The vacuum sampling method involved a direct connection of the evacuated batch cell with the sampling point of the reactor. Thus, the sample was directly sucked from the reactor into the $T B R$, which contained $2 \mathrm{ml}$ of $100 \mathrm{mM}$ cysteine.

\section{Discussion of results}

Experience with the TBR measurements indicated that the gas rate varied with time. This can be explained by the lack of substrate; only the substrate in the reactor medium was available. For the molasses system, Fig. 4 gives the percent decrease of gas rates for the three TBR stirrer systems and conditions (Table 4) and the continuous reactor after turning off the feed. The gas rate measured in the fluidized bed TBR is seen to have the smallest decrease with time. Because of this and of the visual evidence that the biomass remained relatively intact on the sand, the fluidized bed TBR was chosen as the best system. The decrease of gas rate with time made it important that the measurements be made immediately after sampling, even one minute made a considerable difference in the results. The molasses-fed reactor gave gas rates which followed a kinetic saturation curve as given in Fig. 5. This set of data indicates a $K_{S}$ value of approximately $3 \mathrm{~kg} \mathrm{COD} / \mathrm{m}^{3}$. Comparison of the gas rates obtained from the TBR as scaled up according to the sand volume gave the results for the two methods of sampling, also in Fig. 5. Both the vacuum and the hypodermic sampling gave the same results. Cysteine was always used, since without this poising agent the gas rates were reduced by 50 percent. 


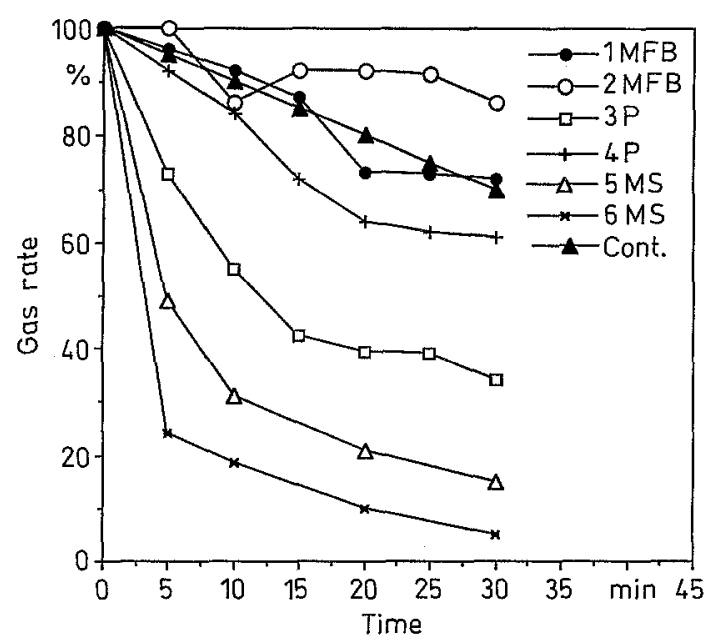

Fig. 4. Influence of mixing and sample solid/liquid ratio on the gas production rates (refer to Fig. 3 and Table 4). Measurements 1-6 made in the TBR from continuous reactor samples with conditions of $S_{1}=2.14 \mathrm{~kg} \mathrm{COD} / \mathrm{m}^{3}$ and residence time $=3.3 \mathrm{~h}$. Measurements - - Cont. measured directly in continuous reactor 0.81 after turning the feed off

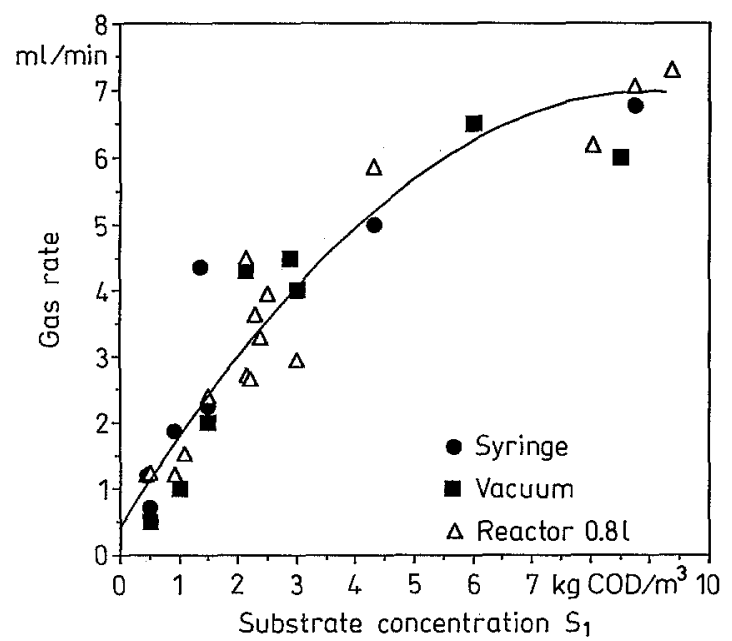

Fig. 5. Comparison of scaled-up TBR gas rates for two sampling methods with the continuous reactor

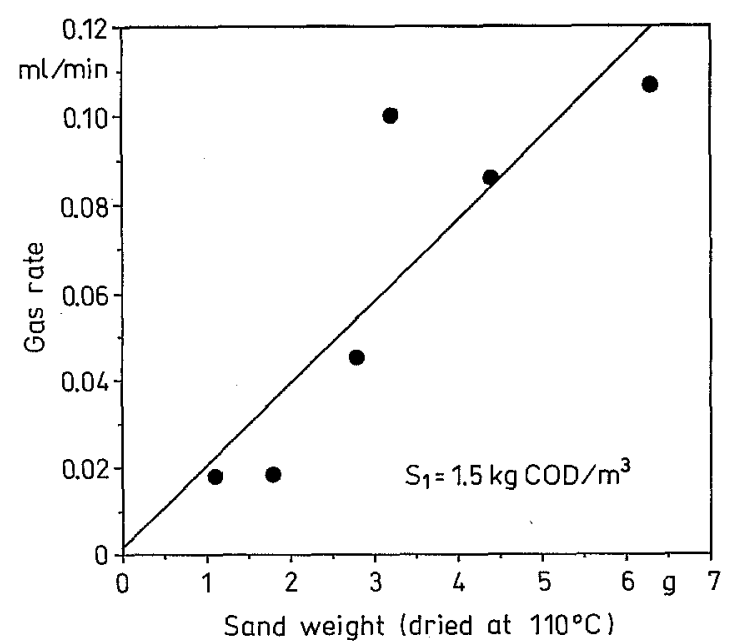

Fig. 6. Correlation of sample size with TBR gas production rates

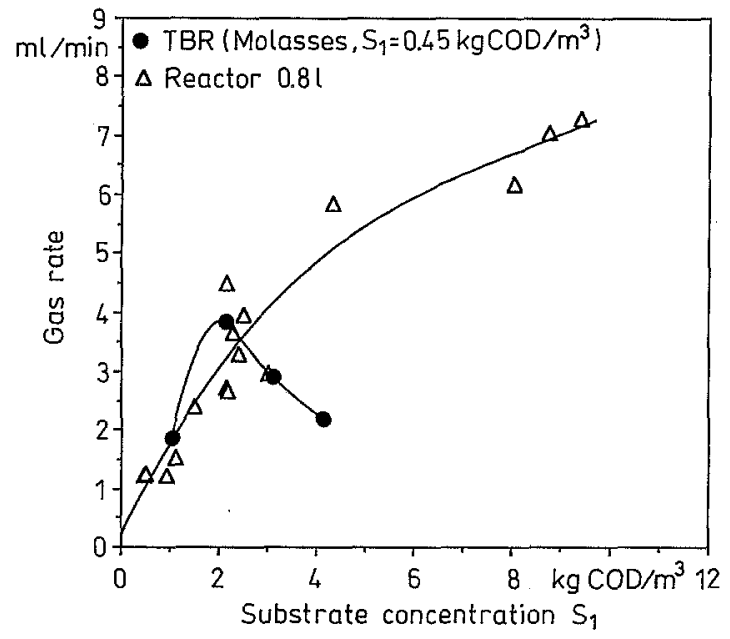

Fig. 7. Influence of molasses substrate addition on the TBR gas rates

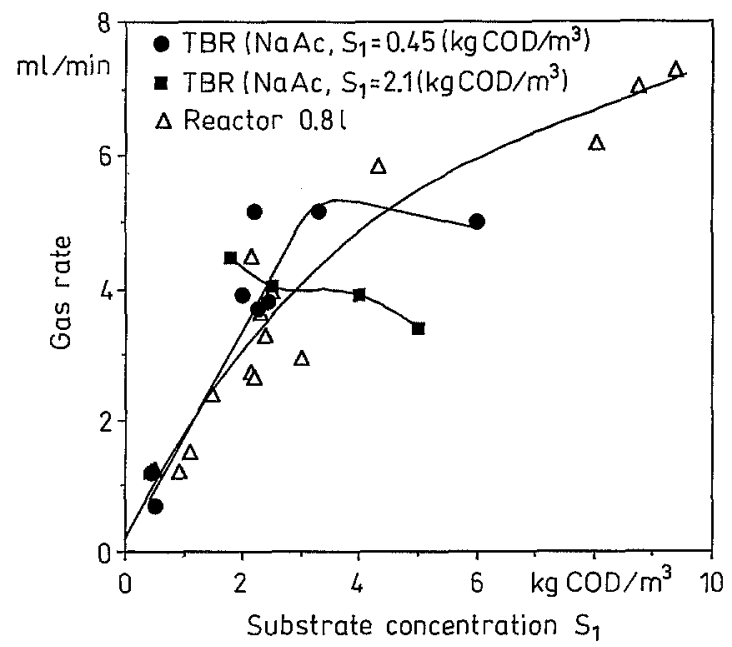

Fig. 8. Influence of sodium acetate substrate addition on the TBR gas rates

The TBR was used to compare the activity of a liquid sample with that of the sand-biomass solid sample. The data for three molasses-fed steady states are given in Table 3. Apparently the liquid, with whatever suspended biomass was also present, did not represent more than $2 \%$ of the total activity of the sample. Thus the relative amounts of sand in the samples and in the reactor could be important because it could not simply be added to the TBR; the substrates available to the organisms in the steady state reactor was a complex mixture and was therefore no longer simply molasses. A somewhat different approach would be to measure the changing gas production over a period of hours or days to observe a maximum in gas rates for a given substrate addition [2]. This would have to be combined with $\mathrm{pH}$ control or buffering. It would however not be useful for measuring the specific activity dependence on reactor conditions.

Specific gas production rates for the brewery and the vapor condensate waste systems are compared with the cor- 


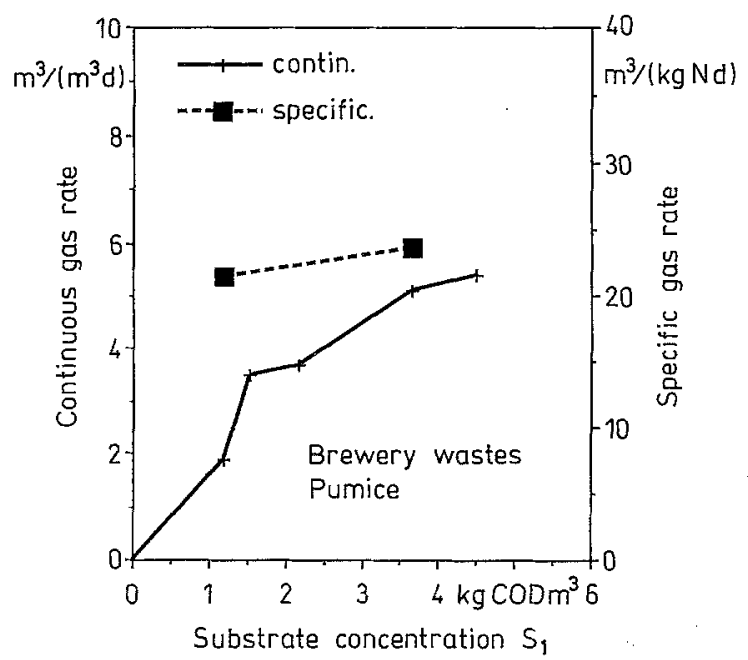

Fig. 9. Comparison of the specific TBR gas rates with the continuous reactor gas rates for the pumice-brewery waste system

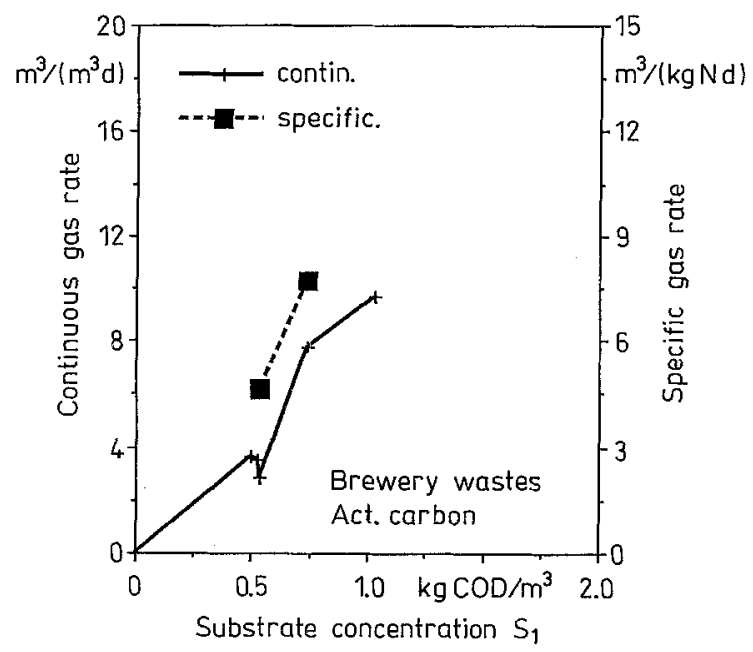

Fig. 10. Comparison of the specific TBR gas rates with the continuous reactor gas rates for the activated carbon-brewery waste system

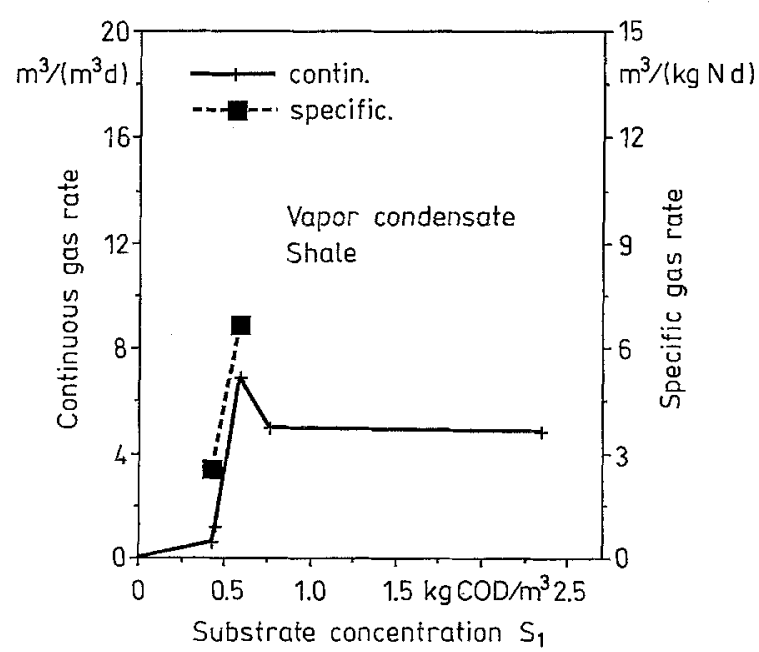

Fig. 11. Comparison of the specific TBR gas rates with the continuous reactor gas rates for the shale-vapor condensate system

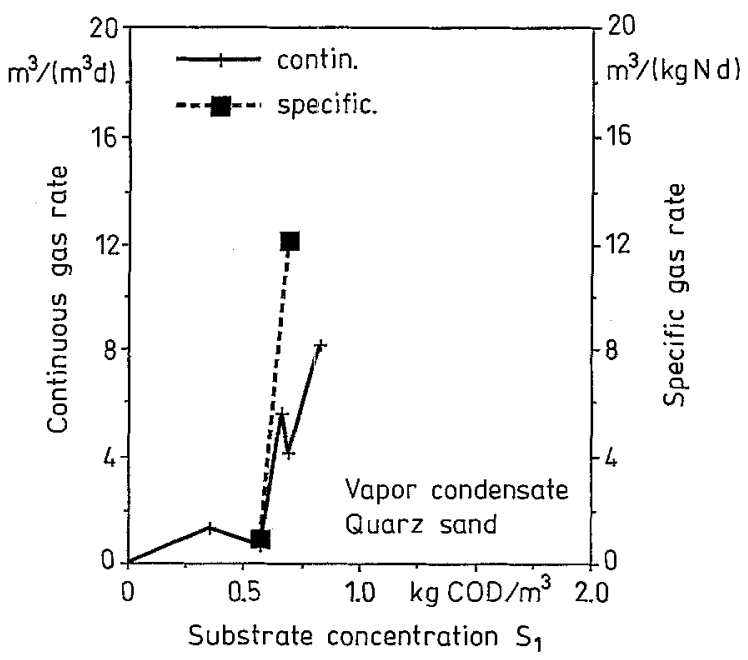

Fig. 12. Comparison of the specific TBR gas rates with the continuous reactor gas rates for the quartz sand-vapor condensate system

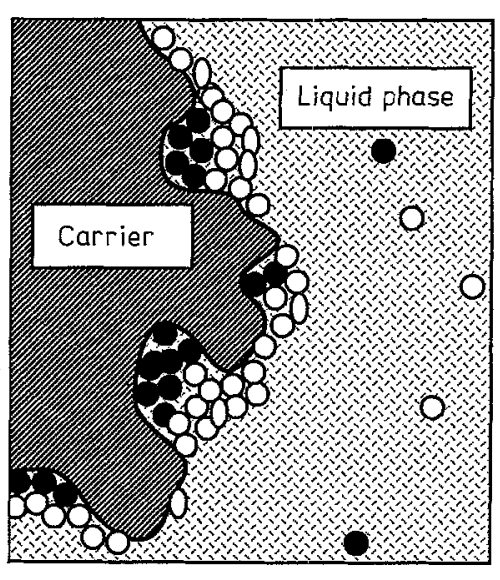

Inactive biomass $\mathrm{O}$ Active biomass

Fig. 13. Schematic of biomass distribution on a porous carrier surface

responding continuous reactor gas rates, each for two carriers. Thus for the brewery waste, the reported carrier data is for pumice (Fig. 9) and activated carbon (Fig. 10), and for the vapor condensate waste the data is from reactors with shale (Fig. 11) and quartz (Fig. 12) carriers. For these systems the total methane and carbon dioxide gas rates are reported. Comparison of Figs. 9 and 10 reveals that for the lowest substrate $\left(0.75 \mathrm{~kg} \mathrm{COD} / \mathrm{m}^{3}\right)$ concentration conditions, the data from the continuous reactor show values of 1.2 and $7.8 \mathrm{~m}^{3} / \mathrm{m}^{3} \mathrm{~d}$; thus the activated carbon reactor was approximately 6 times more active than the pumice reactor. The specific rates were 14 and $7.8 \mathrm{~m}^{3} / \mathrm{kg} \mathrm{N} \mathrm{d}$; thus the biomass on the pumice had a specific activity twice that of the biomass on the activated carbon. An explanation for this might be that the much higher internal area of the activated carbon (Table 2) held not only more active biomass but also retained more inactive biomass (Fig. 13). For the vapor condensate system, the data in Figs. 11 and 12 exhibit the same 
qualitative comparison $\left(0.75 \mathrm{~kg} \mathrm{COD} / \mathrm{m}^{3}\right)$ : the carrier with the highest pore area, in this case shale as compared with quartz sand, gave the highest continuous rate (5.2 versus $6.3 \mathrm{~m}^{3} / \mathrm{m}^{3} \mathrm{~d}$ ) but gave the lowest specific rate (8 versus $17 \mathrm{~m}^{3} / \mathrm{kg} \mathrm{N} \mathrm{d}$ ). Remarkable is the fact that the trends of the continuous and the specific data for the four systems in Figs. 9-12 were the same. Thus it was found that the specific and continuous rates for all systems increased in the same manner with increasing substrate conditions.

\section{Conclusions}

1) Sampling of the anaerobic biomass from a continous reactor required the use of a poising agent (cysteine) to retain the biomass activity.

2) The vacuum and the syringe sampling methods gave the same results.

3) A test batch fluidized bed reactor (TBR) was designed to measure small gas production rates using a U-tube, which provided the best results in terms of a minimum decrease in activity of the sample with time.

4) Scaling up the TBR measurements, based on the settled volume of carrier, allowed favorable comparison with the continuous measurements, which gave confidence that the data was accurate.

5) The liquid phase activity was small compared to the activity of the attached biomass and could be neglected. However, if the liquid phase activity were significant then this must be taken into account.

6) Experiments to measure the kinetics by adding additional substrate (molasses and acetate) to the TBR demonstrated that this is not a valid method to simulate the conditions in the continuous reactors. The use of the TBR is therefore restricted to immediate measurement of the sample in the medium taken from the continuous reactor.

7) Specific measurements require the determination of the biomass on the carrier. Organic nitrogen content was found to be a satisfactory and accurate method, which also permitted the measurement of biomass content on activated carbon.

8) The method is inexpensive and easy to handle.

Evaluation of the specific and continuous data obtained in these experiments leads to the conclusion that total biomass retention was enhanced by the porosity of the carrier. This may be partially due to the lower liquid flow velocities used with the porous materials [4], due to their lower densities (Table 2). The continuous gas production rates were not always highest for the highest biomass retention. In the case of vapour condensate wastewater, the continuous and specific rates were highest for the carrier (quartz) with the lowest porosity and therefore the lowest total biomass retention.

Although the exact waste water influence and the interaction between carrier and bacteria remains scarcely known, the availability of the specific rates by the present TBR method greatly aids the interpretation of these complex effects.

\section{Acknowledgments}

The authors are grateful for a joint Swiss government (KWF)-industry research (Gebr. Sulzer AG) grant which made part of this work possible, and for the cooperation of the Cellulose AG Attisholz, and Hurlimann Brewery for supplying the wastewater.

The authors wish to thank Dr. O. M. Kut for useful discussion of the manuscript.

\section{References}

1. Petrozzi, S.; Dunn, I. J.: Gas measurement methods for laboratory-scale anaerobic reactors. Biotechnol. Tech. 5 (1991) 355358

2. Owen, W. F; Stuckey, D. C.; Healy, J. B., Jr.; Young, L. Y.; McCarty, P. L.: Bioassey for monitoring biochemical methane potential and anaerobic toxicity. Water Res. 13 (1979) 485-492

3. Dunn, I. J.; Petrozzi, S. : Startup of anaerobic biofilm fluidized bed reactors on molasses and phenol under various conditions. Bioprocess Eng. 6 (1991) 21-28

4. Petrozzi, S.; Dunn, I. J.; Heinzle, E.; Kut, O. M.: Carrier influence in anaerobic biofilm fluidized beds for treating vapor condensate from the sulfite cellulose process. Can. J. Chem. Eng. 69 (1991) 527-533

5. Chiang, C. F; Dague, R. R.: Determination of acetoclastic methanogenic activity in anaerobic systems. $43^{\text {rd }}$ Purdue Ind. Waste Conf. Proc. (1989) 353-361

6. Dissing, U.; Ling, T. G.; Mattiasson, B.: Monitoring of methanogenic processes with an immobilized mixed culture in combination with a gas-flow meter. Anal. Chim. Acta 163 (1984) $127-133$

7. Van den Berg, L.; Lentz, C. P.; Athey, R. J.; Rooke, E. A.: Assessment of methanogenic activity in anaerobic digestion: Apparatus and method. Biotechnol. Bioeng. 16 (1974) 1459 1469

8. Battersby, N. S.; Wilson, V.: Evaluation of a serum bottle technique for assessing the anaerobic biodegradability of organic chemicals under methanogenic conditions. Chemosphere 17 (1988) $2441-2460$

9. Shelton, D. R.; Tiedje, J. M.: General method for determining anaerobic biodegradation potential. Appl. Environ. Microbiol. 47 (1984) $850-857$

10. Yamada, N.; Heinzle, E.; Dunn, I. J.: Kinetic studies on methanogenic cultures using mass spectrometry. Biochemical Engineering. vol, 2 (Eds.: Reuss, M., Knackmuss, Chmiel, Gilles), G. Fischer, Stuttgart, in press

11. Moyer, C. L.; Morita, R. Y.: Effect of growth rate and starvation-survival on cellular DNA, and protein of a psychrophilic marine bacterium. Appl. Environ. Microbiol. 55 (1989) 2710 2716

12. Chung, Y.-C.; Neethling, J. B.: ATP as a measure of anaerobic sludge digester activity. J. Water Pollut. Control Fed. 60 (1988) $107-112$

13. Johnson, I. R.; Stafford, D. A.: Control of activated-sludge process using ATP measurements. Miocrobiol. Methods Environ. Biotechnol. (1984) 183-195

Received October 23, 1991

S. Petrozzi

N. Mol

I. J. Dunn (corresponding author)

Biological Reaction Engineering Group

Chemical Engineering Department

ETH

8092 Zürich, Switzerland 